\title{
Pengaruh Motivasi, Kepuasan Kerja dan Disiplin Kerja terhadap Kinerja Karyawan pada PT. Bahtera Bahari Shipyard
}

\author{
Dhiya Ulha Qiyah \\ Universitas Putera Batam \\ pb160910379@upbatam.ac.id \\ Mauli Siagian \\ Universitas Putera Batam \\ maulisiagian@puterabatam.ac.id
}

\begin{abstract}
Abstrak This study aims to determine empirically about the influence of motivation, job satisfaction and work discipline on the performance of the employees of PT Bahtera Bahari Shipyard. A sample of 155 respondents. The instrument used to collect data was a questionnaire. The sampling technique used is Random Sampling where sampling provides equal opportunities for each element or member of the population to be selected as a sample. Test data in this study are validity, reliability, classic assumptions, multiple linear analysis of the coefficient of determination ( $R 2), t$ test and $f$ test. The data was processed using SPSS version 25. The results of the study found t count $>$ $t$ table is 4.807> 1.976 and a significant value of $0.000<0.05$. This means that motivation has a positive and significant effect on the performance of employees of PT Bahtera Bahari Shipyard. $t$ calculate the known job satisfaction> t table is 2.290> 1.976 and a significant value of $0.000<0.05$. This means that job satisfaction has a positive and significant effect on the performance of the employees of PT Bahtera Bahari Shipyard. $t$ calculate known work discipline > t table is 4.174> 1.976 and a significant value of $0.000<0.05$. This means that work discipline has a positive and significant effect on the performance of the employees of PT Bahtera Bahari Shipyard. And there is motivation, job satisfaction and employee discipline together have a positive and significant effect on employee performance. Evidenced by the results of the F test (simultaneous) F value of 27,197 (Fcount)> 3.05 (Ftable). And the value is significant at $0,000<0.05$.
\end{abstract}

Kata Kunci Motivation, Job Satisfaction, Work Discipline, Employee Performance

\section{PENDAHULUAN}

Perkembangan di Kota Batam saat ini khususnya untuk mendorong sumber daya manusia menjadi salah satu faktor yang paling penting dalam mencapai tujuan perusahaan.karena kekuatan sumber daya manusia sangatlah penting bagi suatu perusahaan.Sumber daya manusia salah satu ciri sumber daya yang bekinerja baik dalam melaksanakan tugas dan tanggung jawab yang tinggi bahkan tidak dapat dilepaskan dari sebuah organisasi pernyataan ini didukung oleh (Hilmawan, 2019:167). Perusahaan dapat berjalan sesuai dengan apa yang diharapkan apabila didalamnya terdapat manusia dengan 
satu tujuan yang sama, yaitu berkeinginan untuk menjadikan perusahaan tempat dia bekerja mengalami peningkatan keuntungan serta perkembangan dari hari ke hari menurut (Nata \& Reza, 2017:17).

Perusahaan harus dapat mengetahui cara-cara di mana perusahaan dapat meningkatkan salah satunya dengan memotivasi karyawan itu sendiri. Motivasi sangat penting diperhatikan oleh perusahaan yang ingin setiap karyawannya berkontribusi secara aktif terhadap pencapaian perusahaan, karena motivasi seorang karyawan akan memiliki semangat yang besar dalam menjalankan fungsi dan tanggung jawabnya dengan baik.

Faktor lain yang dapat mempengaruhi kinerja karyawan adalah kepuasan kerja. Kepuasan kerja mengacu pada sikap karyawan terhadap pekerjaannya. kepuasan kerja sebagai bentuk ekspresi perasaan seseorang terhadap pekerjaannya. PT. Bahtera Bahari Shipyard (BBS) adalah sebuah perusahaan yang bergerak di industri perkapalan yang berdiri di Batam tahun 2005. PT. Bahtera Bahari Shipyard(BBS) adalah galangan yang melaksanakan pembuatan kapal yang ditunjang dengan sarana pokok berupa lokasi daratan yang cukup luas ber alamat Jl. Patimura No.1, Kabil, Kecamatan Nongsa, Kota Batam, Kepulauan Riau 29467. Seseorang yang memiliki kepuasan kerja yang tinggi akan merespons dengan sikap positif terhadap pekerjaannya, sementara seseorang yang memiliki kepuasan kerja yang rendah dengan pekerjaannya akan merespons dengan sikap negatif terhadap pekerjaannya. Studi sebelumnya yang telah membahas pengaruh kepuasan kerja terhadap kinerja karyawan telah menyebabkan kepuasan kerja yang mempengaruhi kinerja karyawan.

Upaya meningkatkan kinerja karyawan tidak lepas dari disiplin karyawan. Pernyataan ini didukung oleh (Pramularso, 2017:171) menyatakan bahwa Disiplin kerja bagian dari sikap berperilaku yang tidak bisa terpisahkan dalam mematuhi peraturan yang ada. Dengan adanya peraturan tentang sikap, tindakan, dan perilaku karyawan dapat digunakan sebagai titik pacuan bagi perusahaan dalam mendefinisikan aturan, serta sebagai pengetahuan bagi karyawan tersebut. Jika karyawan tidak disiplin, mereka secara akan mengganggu pekerjaan dan kegiatan karyawan lainnya, seharusnya pekerjaan harus diselesaikan hari ini, dan ternyata masih banyak pekerjaan yang tertunda dan tidak dapat diselesaikan tepat waktu. Didalam peraturan ini diharapkan dapat dijalankan dengan baik agar tidak mengganggu aktivitas perusahaan, sehingga kinerja karyawan akan lebih mudah ditingkatkan.

Masalah dalam kinerja karyawan salah satunya kurangnya keterbukaan di perusahaan, mulai dari masalah yang telah terjadi, dampak dari masalah hingga keputusan yang diambil untuk menyelesaikannya. Karyawan akan menebak masalah yang terjadi dalam perusahaan, sehingga muncul rumor bahwa citra perusahaan rusak. Pemimpin yang tidak bijaksana dalam berperilaku terhadap karyawan dapat mengalami kurangnya motivasi dari pemimpin. Pemimpin yang tidak memberi karyawan berdasarkan keterampilan yang mereka miliki sehingga karyawan tidak memiliki terhadap pekerjaan.

\section{KAJIAN PUSTAKA Motivasi}

Motivasi adalah dimana ada sesuatu di dalam diri seseorang yang mensupport dirinya sendiri untuk melakukan kegiatan yang berguna untuk mencapai tujuan organisasi (Siagian, 2018:26). Sedangkan Menurut (Siti \& Hariyadi, 2019:52) motivasi adalah suatu dukungan yang diberikan kepada kita oleh orang lain, sehingga mereka ingin melakukan perubahan pada diri kita sendiri. Variabel Motivasi menurut (Setiawan \& Mulyapradana, 2019) terdapat indikator yang mempengaruhi motivasi, yaitu ; 
1. Perilaku karyawan

2. Usaha karyawan

3. Kegigihan karyawan

\section{Kepuasan kerja}

Menurut (Susmiati \& Jajuk, 2017) Kepuasan kerja adalah suatu sikap umum dari hasil beberapa sikap khusus terhadap faktor-faktor pekerjaan, karakteristik individual, serta hubungan kelompok diluar pekerjaan itu sendiri.

Menurut (Redi, 2018:27) ada 3 indikator dari kepuasan kerja , yaitu:

1. Kepuasan terhadap gaji

2. Kepuasan terhadap pekerjaan itu sendiri

3. Kepuasan kesempatan

\section{Disiplin Kerja}

Menurut (Setiawan \& Aan Khurosani, 2018) Disiplin kerja merupakan kesadaran dan ketaatan diri seseorang terhadap peraturan baik tertulis maupun tidak tertulis .Menurut (Nurmaidah, 2018:113) ada 3 indikator dari disiplin kerja, yaitu :

1. Peraturan jam masuk, pulang dan jam istirahat.

2. Peraturan cara-cara melakukan pekerjaan

3. Peraturan cara berpakaian dan tingkah laku dalam pekerjaan.

\section{Kinerja Karyawan}

Menurut (Syarkani, 2017:369) Kinerja adalah suatu hasil yang bisa dijadikan pacuan untuk karyawan yang bekerja sesuai dibidang masing-masing yang berlaku untuk pekerjaannya. Menurut (Siagian, 2018) terdapat indikator untuk kinerja karyawan adalah sebagai berikut:

1. Pengetahuan karyawan berdasarkan pekerjaan utama.

2. Kuantitas pekerjaan.

3. Kualitas pekerjaan.

4. Karyawan dapat melaksanakan pekerjaan tepat waktu.

\section{KERANGKA PIKIRAN}

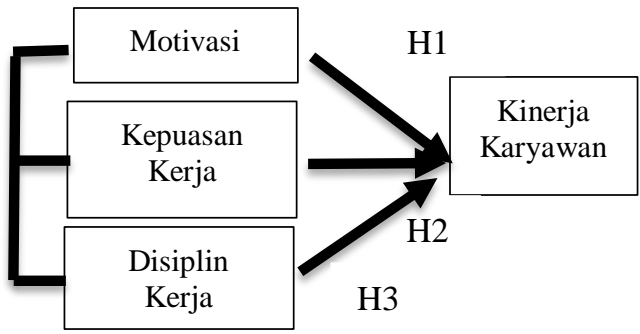

Gambar 1. Kerangka Pemikiran

(Sumber: Peneliti, 2020)

\section{Hipotesis}

H1 $_{1}$ : Motivasi berpengaruh terhadap kinerja karyawan pada PT Bahtera Bahari Shipyard di Kota Batam

$\mathbf{H}_{2}$ : Kepuasan kerja berpengaruh terhadap kinerja karyawan pada PT Bahtera Bahari Shipyard di Kota Batam

$\mathbf{H}_{3}$ : Disiplin kerja berpengaruh terhadap kinerja karyawan pada PT Bahtera Bahari Shipyard di Kota Batam

$\mathbf{H}_{4}$ : Motivasi, Kepuasan Kerja dan Disiplin kerja secara simultan berpengaruhh terhadap kinerja karyawan pada PT Bahtera Bahari Shipyard di Kota Batam

\section{Metode Penelitian}


Desain penelitian didefinisikan rancangan yang dimaksut pada penelitian, membuat rumusan masalah yang di ajukan terjawab dengan saksama. Penelitian menggunakan penelitian deskriptif yang menerapkan metode pendekatan kuantitatif. Peneliti untuk penelitian ini menggunakan penelitian deskriptif analisis dengan pendekatan kuantitatif yaitu dimana menganalisis dan mengelola untuk mengambil keputusan. (Sugiyono, 2018, p. 13)

Penelitian ini menggunakan teknik random sampling, yaitu teknik pengambilan sampel yang memberikan peluang yang sama bagi setiap unsur atau anggota populasi untuk dipilih menjadi sampel dengan menggunakan rumus rumus slovin, jumlah sampel dalam penelitian ini menggunakan rumus slovin dengan tingkat toleransi kesalahan 5\% Sampel dalam penelitian ini sebanyak 155 orang. Jadi, sampel dalam penelitian ini adalah 155 responden karyawan PT. Bahtera Bahari Shipyard.

\section{Hasil dan Pembahasan Profil Responden}

Profil responden dalam penelitian ini akan membahas lima jenis karakteristik responden yaitu bedasarkan jenis kelamin, pendidikan terakhir, usia, jabatan. Pengumpulan data dilakukan dengan menyebar kuesioner sebanyak 155 responden, karakteristik responden yang di dapatkan peneliti di olah dengan menghasilkan karakteristik responden dengan menggunakan aplikasi SPSS 25 dan membuat tabel berupa data distribusi frekuensi responden. Untuk responden laki-laki sebanyak menjelaskan bahwa responden laki - laki sebanyak 132 atau 85,2\% dan perempuan sebesar 23 atau 14,8\% dari total jumlah 155 responden. Dapat diketahui bahwa Mayoritas karyawan yang bekerja di PT Bahtera Bahari Shipyard adalah laki-laki dikarenakan pekerjaan yang dilakukan di PT Bahtera Bahari Shipyard merupakan pekerjaan yang membutuhkan tenaga fisik yang kuat.

Responden dengan usia 20 - 30 tahun sebanyak 27 responden atau setara dengan $17,4 \%$, usia 31 - 40 tahun sebanyak 56 atau setara dengan $36.1 \%$ selanjutnya usia $41-$ 50 tahun terdapat 59 orang atau setara dengan $38.1 \%$, dan karakteristik responden dengan usia $>50$ tahun adalah 13 atau dengan tingkat persentasenya adalah 8,4\% dari total 155 responden.responden berdasarkan pendidikan terakhir adalah tingkat SMP mencapai 7 orang atau setara denga 4,5\% dan merupakan jumlah responden yang paling sedikit dari total 155. responden. kemudian jumlah responden pada tingkat pendidikan SMA yaitu 60 setara dengan 38,7\% merupakan responden terbanyak dari total 155 responden, dan Diploma sebanyak 35 setara dengan 22,6\%. Terakhir dari pendidikan Sarjana yaitu 53 orang dan tingkat persentasenya $34,2 \%$. karakteristik responden berdasarkan jabatan adalah: untuk office sebanyak 17 responden setara dengan $11,0 \%$, selanjutnya untuk jabatan store adalah 13 dengan persentase 8,4\% dari total 155 reponden, helper sebanyak 22 atau setara dengan $14.2 \%$ dari total 155 responden, lalu HSE sebanyak 4 dengan persentase $2,6 \%$, operator crane sebanyak 13 atau setara dengan $8.4 \%$, mekanik sebanyak 12 atau setara dengan 7,7\%, elektrik 20 dengan percentase 12,9\%, QC 15 dengan percent $9,7 \%$, engineering sebanyak 13 dengan percent $8,4 \%$, dan yang memiliki jabatan lain yaitu welder sebanyak 26 dengan total percent $16,8 \%$ merupakan yang paling tinggi dari 155 responden.

\section{Hasil Kualitas Data}

Tabel 1. Hasil Uji Validitas Variabel Motivasi 


\begin{tabular}{|c|c|c|c|}
\hline Pernyataan & r hitung & $\begin{array}{c}\text { r tabel } \\
\alpha=5 \%\end{array}$ & Keterangan \\
\hline$\left(X 1 \_1\right)$ & 0.538 & 0.158 & Valid \\
\hline$\left(X 1 \_2\right)$ & 0.669 & 0.158 & Valid \\
\hline X1_3) & 0.726 & 0.158 & Valid \\
\hline (X1_4) & 0.702 & 0.158 & Valid \\
\hline
\end{tabular}

(Sumber: Hasil Pengolah Data SPSS 25, 2020)

Tabel 2. Hasil Uji Validitas Variabel Kepuasan Kerja

\begin{tabular}{|c|c|c|c|}
\hline Pernyataan & r hitung & $\begin{array}{c}\text { r tabel } \\
\alpha=5 \%\end{array}$ & Keterangan \\
\hline$\left(\mathrm{X} 2 \_1\right)$ & 0.605 & 0.158 & Valid \\
\hline (X2_2) & 0.673 & 0.158 & Valid \\
\hline (X2_3) & 0.782 & 0.158 & Valid \\
\hline (X2_4) & 0.751 & 0.158 & Valid \\
\hline
\end{tabular}

(Sumber: Hasil Pengolah Data SPSS 25, 2020)

Tabel 3. Hasil Uji Validitas Variabel Disiplin Kerja

\begin{tabular}{|c|c|c|c|}
\hline Pernyataan & r hitung & $\begin{array}{c}\text { r tabel } \\
\alpha=5 \%\end{array}$ & Keterangan \\
\hline (X3_1) & 0.732 & 0.158 & Valid \\
\hline (X3_2) & 0.735 & 0.158 & Valid \\
\hline (X3_3) & 0.703 & 0.158 & Valid \\
\hline (X3_4) & 0.702 & 0.158 & Valid \\
\hline
\end{tabular}

(Sumber: Hasil Pengolah Data SPSS 25, 2020)

Tabel 4. Hasil Uji Validitas Variabel Kinerja Karyawan

\begin{tabular}{|c|c|c|c|}
\hline Pernyataan & r hitung & $\begin{array}{c}\text { r tabel } \\
\alpha=5 \%\end{array}$ & Keterangan \\
\hline$(\mathrm{Y} 1)$ & 0.702 & 0.158 & Valid \\
\hline$(\mathrm{Y} 2)$ & 0.658 & 0.158 & Valid \\
\hline$(\mathrm{Y} 3)$ & 0.721 & 0.158 & Valid \\
\hline (Y4) & 0.686 & 0.158 & Valid \\
\hline
\end{tabular}

(Sumber: Hasil Pengolah Data SPSS 25, 2020)

Tabel diatas menjelaskan bahwa seluruh pernyataan pada variabel dependen dan independen dinyatakan valid dikarenakan hasil $r$ hitung $>r$ tabel. Dapat disimpulkan dari hasil pengujian validitas bahwa pernyataan pada variabel dependen dan independen bisa diterima.

Tabel 5. Hasil Uji Reliabilitas

\begin{tabular}{|l|c|c|}
\hline \multicolumn{1}{|c|}{ Variabel } & \multicolumn{1}{|c|}{$\begin{array}{c}\text { Cronbach's } \\
\text { Alpha }\end{array}$} & Keterangan \\
\hline Motivasi (X1) & 0.635 & Reliabel \\
\hline Kepuasan Kerja (X2) & 0.664 & Reliabel \\
\hline Disiplin Kerja (X3) & 0,737 & Reliabel \\
\hline Kinerja Karyawan (Y) & 0.801 & Reliabel \\
\hline
\end{tabular}

(Sumber: Hasil Pengolah Data SPSS 25, 2020)

Uji reliabilitas memperlihatkan hasil pengukurannya apabila pengukuran dilakukan lebih dari satu kali. dari tabel 5, dapat dilihat hasil uji reliabilitas setiap variabel 
memperoleh Cronbach's alpha yang bernilai melebihi 0.6, sehingga seluruh variabel dinyatakan reliabel atau dapat diterima.

\section{Hasil Uji Asumsi Klasik \\ UJi Normalitas}

Tabel 6. Hasil Uji Normalitas

\begin{tabular}{|ll|r|}
\hline \multicolumn{2}{|c|}{ One-Sample Kolmogorov-Smirnov Test } \\
\hline Normal Parameters ${ }^{a, b}$ & Mean & $\begin{array}{c}\text { Unstardized } \\
\text { Residual }\end{array}$ \\
\hline Norme Differences & Std. Deviation & 155 \\
Most Extremelute & .0000000 \\
& Positive & 1.576744488 \\
& Negative & .040 \\
Test Statistic & & .028 \\
Asymp. Sig. (2-tailed) & -.040 \\
\hline
\end{tabular}

(Sumber: Hasil Pengolah Data SPSS 25, 2020)

Uji normalitas memiliki fungsi untuk memberikan distribusi normal suatu data. Menurut tabel 6, dapat dilihat bahwa nilai probabilitas signifikan senilai $0.200^{\mathrm{dc}}$, nilai ini melebihi taraf signifikansi 0,05 maka pengujian normalitanya terpenuhi.

Gambar 1 Histogram dan Grafik P-Plot
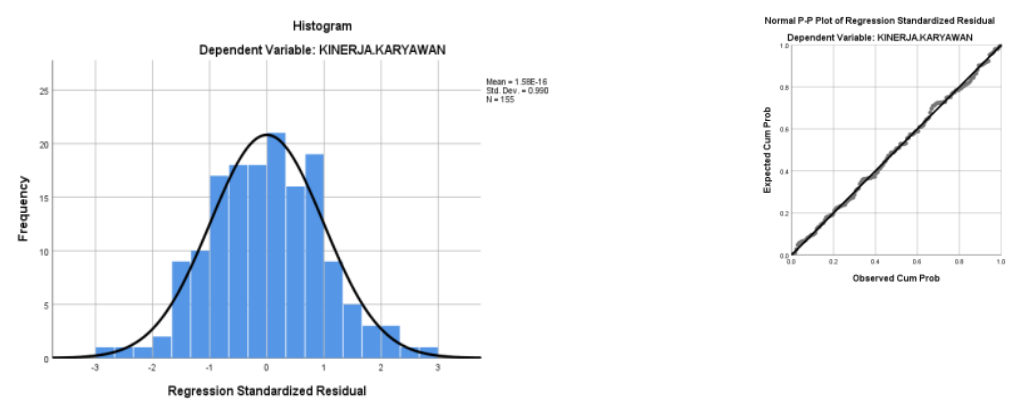

(Sumber: Hasil Pengolahan Data SPSS 25, 2020)

Terlihat dari gambar 4.1, terlihat kurva histogram tersebut menunjukkan data tidak berdistribusi normal, pernyataan ini ditandai dengan adanya instabilitas karena kategori yang ditentukan oleh peneliti dari lama bekerja yang belum memadai atau jangka waktu bekerja yang cenderung pendek sehingga responden dalam memberikan jawaban belum memiliki nilai yang persisten. Jawaban sementara dari peneliti atas fenomena yang ditunjukkan pada uji histogram ialah adanya peluang dari banyaknya kategori data yang mengontrol variabel supaya terarah.

Tabel 7. Hasil Uji Multikolinearitas

\begin{tabular}{|l|l|c|}
\hline Variabel & Collinearity Statistics & Keterangan \\
\hline
\end{tabular}




\begin{tabular}{|c|c|c|c|}
\cline { 2 - 3 } & Tolerance & VIF & \multicolumn{1}{|c|}{} \\
\hline Motivasi & 0.889 & 1.125 & Bebas multikolinearitas \\
\hline Kepuasan Kerja & 0.815 & 1.227 & Bebas multikolinearitas \\
\hline Disiplin Kerja & 0.834 & 1.198 & Bebas multikolinearitas \\
\hline
\end{tabular}

(Sumber: Hasil Pengolahan Data SPSS 25, 2020)

Seperti pada tabel di atas, seseorang dapat mengetahui nilai VIF untuk variabel motivasi (X1) sebesar 1,125 dengan angka toleransi 0,889, kepuasan kerja (X2) sebesar 1,227 menggunakan nilai toleransi sebesar 0,815, disiplin kerja (X3) sebesar 1,198 menggunakan nilai toleransi sebesar 0,834. Dapat disimpulkan, dalam contoh regresi, bahwa tidak ada tanda-tanda impotensi berganda antara variabel, karena nilai VIF kurang dari 10 dan nilai toleransi lebih dari sepuluh dan nilai lebih dari Akbar asal 0,1.

Tabel 8. Hasil Uji Heterokedastisitas

\begin{tabular}{|l|c|l|}
\hline Variabel & Signifikansi & \multicolumn{1}{c|}{ Keterangan } \\
\hline Motivasi & 0.070 & Bebas heteroskedastisitas \\
\hline Kepuasan Kerja & 0.069 & Bebas heteroskedastisitas \\
\hline Disiplin Kerja & 0.074 & Bebas heteroskedastisitas \\
\hline
\end{tabular}

(Sumber: Hasil Pengolahan Data SPSS 25, 2020)

Berdasarkan tabel di atas probabilitas atau taraf signifikansi masing-masing variabel bernilai 1,000 sehinga dapat dipastikan semua model tersebut tidak mengalami gejala heterokedastisitas, dengan kata lain korelasi masing-masing variabel dengan nilai residunya menghasilkan nilai yang lebih besar alpha sebesar 0,05 .

Tabel 9. Hasil Analisis Regresi Berganda

\begin{tabular}{|l|l|c|c|}
\hline \multirow{2}{*}{\multicolumn{2}{|c|}{ Model }} & \multicolumn{2}{c|}{ Unstandardized Coefficients } \\
\cline { 3 - 4 } 1 & (Constant) & 3,148 & Std. Error \\
\cline { 3 - 4 } & Motivasi & 0,338 & 1,387 \\
\cline { 2 - 4 } & Kepuasan Kerja & 0,158 & 0,070 \\
\cline { 2 - 4 } & Disiplin Kerja & 0,310 & 0,069 \\
\cline { 2 - 4 } & & & 0,074 \\
\hline
\end{tabular}

(Sumber: Hasil Pengolahan Data SPSS 25, 2020)

Berdasarkan pengolahan data pada tabel diatas dapat diperoleh persamaan regresi sebagai berikut :

$Y=3,148+0,338 X_{1}+0,158 X_{2}+0,310 X_{3}$

\section{Analisis Uji Koefisien Determinasi $\left(\mathbf{R}^{2}\right)$}


Analisis determinasi berguna mencari besaran persentase kemampuan variabel independen secara bersamaan mempengaruhi variabel dependen. Output Model Sumarry mencerminkan hasil uji $\mathrm{R}^{2}$, sebagai berikut :

Tabel 10. Hasil Uji Koefisien Determinasi $\left(\mathrm{R}^{2}\right)$

\begin{tabular}{|c|c|c|c|c|}
\hline Model & $\mathrm{R}$ & R Square & $\begin{array}{c}\text { Adjusted R } \\
\text { Square }\end{array}$ & $\begin{array}{c}\text { Std. Error of the } \\
\text { Estimate }\end{array}$ \\
\hline 1 & $.592^{\mathrm{a}}$ & .351 & .338 & 1.592 \\
\hline
\end{tabular}

a. Predictors: (Constant), Disiplin Kerja,Kepuasan Kerja,Motivasi

b. Dependent Variable: Kinerja Karyawan

(Sumber: Hasil Pengolahan Data SPSS 25, 2020)

\section{Uji Hipotesis}

\section{Pengujian Secara Parsial ( Uji T )}

Uji statistik t digunakan untuk mengetahui pengaruh variabel independen (motivasi, kepuasan kerja dan disiplin kerja) secara individual mempengaruhi variabel dependen (kinerja karyawan). Nilai t tabel dalam penelitian ini adalah 1,976 (dengan melihat $t$ tabel pada tingkat signifikansi 0,05). Hasil uji t untuk penelitian ini dapat dilihat pada tabel berikut:

Tabel 11. Hasil Uji T

\begin{tabular}{|l|c|l|c|}
\hline Variabel & T Hitung & T Tabel & Nilai sig \\
\hline Motivasi & 4.807 & 1.976 & 0.05 \\
\hline Kepuasan Kerja & 2.290 & 1.976 & 0.05 \\
\hline Disiplin Kerja & 4.174 & 1.976 & 0.05 \\
\hline
\end{tabular}

(Sumber: Hasil Pengolahan Data SPSS 25, 2020)

Nilai t hitung variable motivasi $(4,807)$ melebihi nilai t tabel $(1,976)$ atau nilai sig t $(0,000)$ lebih kecil dari $\alpha(0,05)$. Pada output uji tersebut didapati Ho ditolak dan Ha disetujui untuk variable motivasi,artinya secara terpisah variabel motivasi memberikan dampak signifikan pada kinerja karyawan. Nilai t hitung untuk variable kepuasan kerja (2.290) melebihi t tabel $(1,976)$ atau nilai sig $\mathrm{t}(0,000)$ lebih kecil dari $\alpha(0,05)$. Dari pengujian tersebut dipapatkan output bahwa Ho ditolak dan Ha disetujui untuk variabel kepuasan kerja, artinya secara terpisah variabel kepuasan kerja memberikan dampak significant pada kinerja karyawan. Nilai $t$ hitung untuk variabel disiplin kerja (4.174)melebihi t table $(1,976)$ atau nilai sig. $(0,000)$ tidak melebihi dari $\alpha(0,05)$. Dari output tersebut juga mampu dilihat Ho ditolak dan Ha disetujui untuk variable disiplin kerja ,maka kesimpulannya ialah variabel disiplin kerja secara terpisah berdampak pada kinerja karyawan secara signifikan.

\section{Pengujian Secara Simultan ( Uji F )}

F-test dipergunakan dalam upaya mengetahui bukti terkait dugaan ketiga mengenai independent variable yang bersamaan memberikan dampak pada dependent variable. Secara spesifik dalam studi ini, uji F memiliki fungsi untuk menelaah adanya hubungan 
antara motivasi, kepuasan kerja dan disiplin kerja secara simultan pada kinerja karyawan. Dibawah ini output darif-test :

Tabel 12. Hasil Uji F

\begin{tabular}{|c|c|c|c|c|c|c|}
\hline \multicolumn{7}{|c|}{ ANOVA $^{a}$} \\
\hline \multicolumn{2}{|c|}{ Model } & Sum of Squares & $D f$ & Mean Square & $F$ & Sig. \\
\hline \multirow[t]{3}{*}{1} & Regression & 206.879 & 3 & 68.960 & 27.197 & $.000^{\mathrm{b}}$ \\
\hline & Residual & 382.863 & 151 & 2.536 & & \\
\hline & Total & 589.742 & 154 & & & \\
\hline
\end{tabular}

a. Dependent Variable: Kinerja Karyawan

b. Predictors: (Constant), Disiplin Kerja,Kepuasan Kerja,Motivasi

(Sumber: Hasil Pengolahan Data SPSS 25, 2020)

Output uji tersebut memberikan nilai f hitung yakni 27,197 dan nilai f tabel yakni 2,66 sehingga nilai f hitung melebihi nilai $\mathrm{f}$ table dan nilai sig. yaitu 0,000 kurang dari nilai $\alpha 0,05$, kesimpulanya ialah Ho ditolak dan Ha disetujui. Disetujuinya dugaan alternatif memberikan bukti bahwa independent variable motivasi, kepuasan kerja dan disiplin kerja dapat menerangkan keragaman pada dependent variable yakni kinerja karyawa).

Variabel motivasi, kepuasan kerja serta disiplin kerja secara bersamaan memberikan dampa signifikan pada kinerja karyawan. Kesimpulan lainnya ialah variabel motivasi, kepuasan kerja dan disiplin kerja dapat merasionalisasi bagaimana performa pegawai pada PT. Bahtera Bahari Shipyard.

\section{Pembahasan}

Pengaruh Motivsi Terhadap Kinerja Karyawan Pada PT. Bahtera Bahari Shipyard

Uji pada variabel motivasi (X1) mendapati nilai koefisien yakni 0,338 artinya X1 berdampak positif pada kinerja karyawan. Dengan nilai sig. Yakni 0,000 kurang dari 0,05, memberikan kesimpulan adanya hubungan yang signifikan dari variable motivasi dengan kinerja karyawan yang artinya Hipotesis 1 Diterima. Output thitung yakni 4,807 melebihi nilai $t_{\text {tabel }} 1,976$ ini artinya menguatkan bukti atas pengaruh variable motivasi pada kinerja karyawan yang signifikan dan positive.

Pengaruh Kepuasan Kerja Terhadap Kinerja Karyawan Pada Pt. Bahtera Bahari Shipyard

Uji pada kepuasan kerja (X2) mendapati output koefisien yakni 0,158 dan thitung yakni 2.290 melebihi tabel yakni 1,976 serta nilai sig. 0.023 lebih kecil dari 0,05 . Kesimpulannya ialah kepuasan kerja memberikan dampak positive serta signifikan pada kinerja karyawan yang berabrti Hipotesis 2 Diterima.

\section{Pengaruh Disiplin Kerja Terhadap Kinerja Karyawan pada PT. Bahtera Bahari Shipyard}

Output uji dari disiplin kerja (X3) mendapatkan nilai koefisien yaitu 0,310 dan thitung yaitu 4,174 melebihi tabel yakni 1,976 dan nilai sig. 0.000 kurang dari 0,05. Kesimpulannya ialah disiplin kerja memberikan pengaruh positive dan significant pada kinerja karyawan, artinya Hipotesis 3 Diterima. 


\section{Pengaruh Keselamatan Kerja dan Kesehatan Kerja Terhadap Kinerja Karyawan pada PT. Bahtera Bahari Shipyard}

Dari output $f$-test didapatkan nilai f hitung yakni 27,197 melebihi nilai $\mathrm{F}_{\text {tabel }}$ yakni 3,05 dan nilai sig. 0.000 kurang dari 0,05 yang mana kesimpulannya ialah kepuasan kerja serta disiplin kerja secara bersamaan memiliki dampak positive dan signifikan pada kinerja karyawan. Secara singkat Hipotesis 4 Diterima. Dari uji koefisien determinasi didapatkan nilai $\mathrm{R}^{2}$ yakni $0,351(35,1 \%)$. Artinya, kontribusi dampak dari variable motivasi, kepuasan kerja serta variabel disiplin kerja pada variable kinerja karyawan $35,1 \%$ sedangkan $64,9 \%$ dijelaskan variable yang tidak tercantum pada studi ini.

\section{KESIMPULAN}

Motivasi berpengaruh positif dan signifikan terhadap kinerja karyawan PT. Bahtera Bahari Shipyard. Kepuasan Kerja berpengaruh positif dan signifikan terhadap kinerja karyawan PT. Bahtera Bahari Shipyard. Disiplin Kerja berpengaruh positif dan signifikan terhadap kinerja karyawan PT. Bahtera Bahari Shipyard. Motivasi, Kepuasan Kerja dan Disiplin Kerja secara simultan berpengaruh secara positif dan signifikan terhadap kinerja karyawan PT. Bahtera Bahari Shipyard.

\section{DAFTAR PUSTAKA}

Hilmawan, I. (2019). Pengaruh disiplin kerja, motivasi kerja dan kepuasan kerja terhadap kinerja karyawan pada pt. buana centra swakarsa cilegon banten. Jurnal Elektronik, Vol 3 No 3, 167-177.

Nata, \& Reza. (2017). Pengaruh disiplin kerja terhadap kinerja karyawan pada bank perkreditan rakyat. Lembaga Keuangan Dan Perbankan, 2.

Pramularso, E. Y. (2017). Pengaruh Disiplin Kerja terhadap Kinerja Karyawan Cipta Hotel Pancoran Jakarta Selatan. Akademi Manajemen Keuangan BSI Jakarta, I(2), 171178.

Siagian, M. (2018). Peranan Disiplin Kerja Dan Kompensasi Dalam Menderteminasi Kinerja Karyawan Dengan Motivasi Kerja Sebagai Variabel Intervening Pada PT Cahaya Pulau Pura Di Kota Batam. Manajemen, 6(2), 24.

Siti, S., \& Hariyadi. (2019). Pengaruh Kompensasi, Motivasi Dan Disiplin Kerja Terhadap Kinerja Karyawan Universitas Muria Kudus. Jurnal STIE Semarang, 11(1), $52-65$.

Setiawan, S., \& Mulyapradana, A. (2019). Peran Work Motivation Sebagai Variabel Intervening Pengaruh Instrinsic Reward, Supervision Of Work \& Statisfaction Of Compensation Terhadap Employee Performance ( Studi pada Koperasi Kota Pekalongan ). Jurnal Ekonomi \& Ekonomi Syariah, 2(1), 115-125.

Susmiati, \& Jajuk, H. (2017). Pengaruh Kepuasan Kerja Dan Motivasi Kerja Terhadap OCB (Organizational Citizhenship Behavior) Pegawai PT. Angkasa Pura I (Persero) Cabang Bandara Adisutjipto Yogyakarta Susmiati. Jurnal Manajemen Dewantara, 1(1), 73-86.

Redi, Y. (2018). Pengaruh Budaya Organisasi dan Kepuasan Kerja Terhadap Kinerja Karyawan pada PT. Jaya Abadi Sumber Pasifik Kota Jambi. Jurnal Manajemen Dan Kewirausahaan, 9, 24-35.

Nurmaidah, G. (2018). Pengaruh Disiplin Kerja Dan Komunikasi Terhadap Kinerja Karyawan Di PT. Sekar Mulia Abadi Medan. Jurnal Asia Inovasi Dan Kewirausahaan, 03(May). 